
Canadian Journal of Educational Administration and Policy
Revue canadienne en administration et politique de l'éducation

CJEAP

\title{
A Review of Steiner-Khamsi, G., \& Draxler, A. (Eds.). (2018). The State, Business and Education: Public-Private Partnerships Revisited
}

\section{Ardith McGeown Plant}

Number 195, 2021

URI: https://id.erudit.org/iderudit/1075676ar

DOI: https://doi.org/10.7202/1075676ar

See table of contents

Publisher(s)

Department of Educational Administration, University of Saskatchewan

ISSN

1207-7798 (digital)

Explore this journal

Cite this review

McGeown Plant, A. (2021). Review of [A Review of Steiner-Khamsi, G., \& Draxler, A. (Eds.). (2018). The State, Business and Education: Public-Private Partnerships Revisited]. Canadian Journal of Educational Administration and Policy / Revue canadienne en administration et politique de l'éducation, (195), 100-104. https://doi.org/10.7202/1075676ar 
Book Review

Steiner-Khamsi, G., \& Draxler, A. (Eds.). (2018). The State, Business and Education: Public-Private Partnerships Revisited NORRAG Series on International Education and Development Edward Elgar Publishing ISBN 9781788970327

\author{
Reviewed by: Ardith McGeown Plant \\ University of Winnipeg
}

Once upon a time, the 'business' of education was governed by a state or a government, particularly in North America, Western and Central Europe, and Australia. In these regions, education through schooling was viewed as an opportunity for governments to transfer information and knowledge about society to school-age children (Osborne 2008; Tyack \& Cuban, 1995). Depending on when and where one lived, the education sector was predominantly a closed system. Only a few policy actors organized and managed the state's education system through local or national governments. In practice, these governments imposed standards and curriculums through their political administration. The business sector was perceived as an exogenous influence in the education sector; however, in many countries, the latter has evolved from this autonomous government-controlled sector to a hybrid model. Oldham (2017) referred to this shift as enterprise education and Ball and Junemann (2012) have called this change the education sector's polycentricity. In this book, Steiner-Khamsi and Draxler examined this hybrid alternative to traditional schooling models. The State, Business and Education: Public-private partnerships revisited offers an advanced academic review of the private sector's incisive intervention into the education sector. As the title suggests, the book focuses not only on the triad of the state, business and education, but more specifically on Public-Private Partnerships (PPPs). This emerging education industry, represented by PPPs, is revisited in the book with a focus on specific case studies from Argentina, Bangladesh, Brazil, China, India and Syrian refugee camps.

This is the first book in the Network for International Policies and Cooperation in Education and Training (also known as NORRAG) series on international education and development. The editors begin their discussion by introducing the readers to several perspectives on the relationship between education and government, specifically within the context of public and private partnerships. To begin, a diagram on the book cover listed a set of key acronyms in ascending order: EFA (Education for All), MDG (Millennium Development Goals) and SDG (Sustainable Development Goals), a set of principles adopted by the United Nations (UN) in 2015. "The sustainable development goals (SDGs), [...] built on the strategy seeking the millennium development goals (MDGs) to end all forms of poverty [...] by ensuring that all countries whether poor, rich or middle income engage in activities to promote prosperity that is sustainable for all" (Webb et al., 2017, p. 509). NORRAG's purpose is to offer "evidence-based policy decisions that improve equity and quality of education" (NORRAG, 2020, para. 1). In reflection, 
the editors support this purpose through a broad discussion and review of case studies within a human rights framework. These case studies revealed that government partnerships with private sector actors occurred in crisis and post-crisis contexts, particularly in countries that experienced challenges to their financial capabilities.

For the novice in international relations and governance, the editors and authors anticipated some understanding of the globalization of the education sector as well as an understanding of the historical prevalence of businesses and their presence in and among the nations of the world. The variability and inconsistency among the definitions, typology and sources present some challenges to the presumed understanding and knowledge of the global education marketplace. For example, Moschetti, the author of chapter six, acknowledged the inconsistency of the language, not only within this burgeoning field, but also in practice. For example, in Argentina, The National Education Law 2006 refers to all types of schools as 'public', so even private schools are deemed to be "privately-managed public schools" (p. 86). Further, the terminology evoked throughout this book assumes the reader's knowledge of terms like public-private partnerships, P3s or PPPs, NPM (New Public Management), CSOs/NGOs (civil society organizations/ non-governmental organizations) IOs (International Organizations), ILSA (international large-scale student assessments), LFPS (low-free private schools) among many others. For instance, it would be constructive to provide a formal and detailed definition of PPPs; unfortunately, neither the editors nor the chapter authors provided this reference. Thus, to proffer a common understanding, "a P3 is a long-term contractual arrangement between the public and private sectors where mutual benefits are sought and where ultimately (a) the private sector provides management and operating services and/or (b) puts private finance at risk" (Garvin \& Bosso, 2008, p. 162). Typically considered an option to promote a project or inject financial resources into a state-owned enterprise, the business sector has moved from being a supplier to what the editors have identified as a "partner" (p. 1) within the education sector. The editors continued their review of PPPs by examining how the United States and several developing countries are increasingly entering into these partnerships.

\section{Organization and Approach}

The rationale for this book is supported by a question posed by the editors in the first chapter: "given these setbacks, why has the education industry returned in recent years with full force, become an influential actor in public education, and is likely to further expand its role and its geographical reach in the near future?" (p. 2). The editors begin to answer their question by referencing Tyack and Cuban's (1995) research. These authors discussed the many challenges and setbacks on the progress of the education industry in American schools. The term education industry is defined as: "actors in the global education industry - or GEI - [who] see this spending [by the state] as too often inefficient, wasteful, and poorly leveraged by bureaucracies" (Verger et al. 2016, p. 3). For example, Tyack and Cuban examined the initial setbacks experienced by businesses when trying to have any involvement or investment in the education sector. As Tyack and Cuban noted, there was a shift from businesses advocating for centralization of control and regulation of education to the more current position, which presumes that "decentralization, deregulation and choice will cure what is wrong with education" (p. 41). Although as Verger et al. (2016) argued, "education has long been considered as an industry sector, with its distinct set of services and economic transactions [...] this sector, at least in most developed nations, is dominated by state actors in terms of provision, regulation and spending" (p. 3).

In addition, the editors acknowledged three customary responses to answer their hypothesis. It is important to present a brief synopsis of their analysis, which included a discussion of the shift from government to governance, the standardization of education, and an analysis of PPPs as a global solution to local problems. Finally, the authors proposed a system-theoretical perspective that focuses on the interaction between the public and private sectors (pp. 2-9).

\section{PPPs as a global education policy}

The editors advocated that there has been a shift in the education sector, from a government management model to a governance model. As Taylor (2002) acknowledged, there has been a revival of the concept of governance since the 1980's and 1990's. Since that time, the term governance has come to be associated with several important concepts, including "a reduced role for governments, a focus on processes and 
rules, and a dispersion of governing authoring" (Bruhn, 2016, p. 3). This shift was precipitated by two specific events. Firstly, the neoliberal reforms of the 1980s and secondly, the New Public Management (NPM) policies that The Organisation for Economic Co-operation and Development (OECD) countries advocated. A brief overview of these two concepts will offer some context while also serving to further examine the editors' perspective on the governments' rationale to choose PPPs with the private sector.

Harvey (2005) argued that "neoliberalism has, in short, become hegemonic as a mode of discourse" (p. 2), which has involved governments across the globe slowly beginning to pull back from their public sector responsibilities to focus predominantly on their financing and pecuniary duties. In order to demonstrate how neoliberal policies work, the authors explored privatization initiatives in the United States of America (USA), exemplified by a discussion on vouchers and charter schools. For instance, Joanne Barkan's chapter, 'Death by a thousand cuts: Privatizing public education in the USA' could seem out of place in the book's discussion on the global context of the role of business and PPPs in developing countries. However, as Tyack and Cuban noted, businesses in the US could not work with schools for many years, but this relationship has changed over time. This chapter stands out as it analysed how governments in developed countries engage in PPPs with businesses.

The shift in the governance of the education sector with the involvement of the private sector was also examined through a discussion of NPM. The NPM model exemplifies the principles of flexibility, efficiency drive, and innovation (Charbonneau, 2012). As further examined by Hood (1995), "changes in public sector accounting in a number of OECD countries over the 1980s were central to the rise of the "New Public Management" (NPM) and its associated doctrines of public accountability and organizational best practice" (p. 93). As Steiner-Khamsi and Draxler argued, this market-driven education model presented a new role for governments where "target-setting and benchmarking became the key governance tools" (p. 3). This shift in focus allowed the education sector to look to the private sector to adopt a "steering" role in government (Bruhn, 2016, p. 3).

\section{A system-theoretical model}

As noted in the previous section, the editors advocated for a "system-theoretical perspective, which focuses on the interaction between the public and the private sector" (p. 2). This model suggests that PPPs have instigated a "metamorphosis of the public education system" (p. 9). A systems-theoretical perspective specifically addresses how privatization has "transformed how public schools are managed, teachers are hired, students are taught, and parents are involved" (p. 9). At the end of chapter one, two questions are asked: "What happens when two systems (public education system and private education system) interact?" and "How do the two systems change as a result of this interaction?" (p. 7). The editors proposed that neoliberalism and NPM explain the governments' choice of PPPs, instead of the traditional practices of state and government control. Barkan's chapter on the US education system noted that "[education] reformers have successfully made "choice" the subject of the policy debate" (p. 154). Through the dominance of the private sector in the US, PPPs have marketed the preparation of students for twenty-first century skills through alternative education programs, such as the Bridge International Academy or the International Baccalaureate schools.

Relatedly, Verger et al. (Ch. 2) suggested that international actors take on important roles in the privatization of education in two settings. First, "in a broad range of low-income countries where a diffuse network of international agencies is promoting the expansion of so-called low-fee private schools" (p. 22); and second, "in contexts of emergency and humanitarian crises where international agencies of a different nature have advanced pro-school choice and pro-private sector reforms" (p. 22). The authors proposed a bottom-up process of decision-making that does not involve state intervention, but rather choice, as we have seen in the US privatization model. It is not the state that is actively promoting privatization or industry involvement in the education sector, but rather, "the result of private entrepreneurship in education and of families' demand for private schooling" (p. 23), or what is referred to as low-fee private schools (LFPS), which can be found throughout Sub-Saharan Africa and South Asia. The authors acknowledged that although there is some hesitation toward the continuing expansion of private education, many developing countries view LFPS as an opportunity for the poor to access education. An example of these dynamics could be seen in the re-development of Haiti's education after the 2010 earthquake, which could be perceived as a result of "purposeful interventions" (p. 30). In this case, the 
Inter-American Development Bank (IADB) was "selected the main partner of the Haitian government for the reconstruction of the education system" (p. 30). However, as noted by Verger et al., "international actors do not only operate in contexts of fragility for humanitarian reasons, or to cover governmental needs" (p. 16). They further warn: "the urgency of humanitarian crises tends to shift power and policy relationships, with the result that local stakeholders tend to be marginalized in favor of external agents" (p. 27).

\section{Epilogue}

A key idea of the book is that the privatization of education is at a new juncture in emerging economies. "The global market for education is estimated to reach \$5 trillion, with much of this growth expected in Asia and Africa" (p. 106), which is reflected in the fact that "private provision of education grew by 58 percent between 1991 and 2014" (p. 131). At the same time, there is "limited data on low-fee private schools and no current legal frameworks overseeing the registration and regulation of the sector" ( $p$. 133). As examined through the case studies highlighted in the book, "education reforms are the result of a combination of different drivers and the intervention of a diverse range of actors" (p. 31). In the context of privatization, these reforms are supported through the emerging role of PPPs. Returning to the initial question, "why has the education industry returned in recent years with full force, become an influential actor in public education, and is likely to further expand its role and its geographical reach in the near future?" (p. 2). I would argue that while the authors answered the question, it is also important to acknowledge other essential variables. As aptly expressed by Ball (2009), "privatisation is a key strategy in education reform and the reform of the state, but not always an end in itself" (p. 84). This book aptly revealed some of the central tenets of how the state, business, and education converge through PPPs. It is important to acknowledge the role of choice, necessity and public demand, which government officials must understand before engaging in public-private partnerships with the private sector.

\section{References}

Ball, S. J. (2009). Privatising education, privatising education policy, privatising educational research: Network governance and the competition state. Journal of Education Policy, 24(1), 83-99. doi: 10.1080/02680930802419474

Ball, S. J., \& Junemann, C. (2012). Networks, new governance, and education. Policy Press.

Bruhn, J. (2016). Government and governance: A guide for the perplexed. Canada: Stratejuste Canada. https://www.stratejuste.ca/uploads/3/1/8/4/31849453/rb_2_guide_for_the_perplexed_2016.pdf

Charbonneau, M. (2012). New public management. In L. Côté \& J.-F. Savard (Eds.), Encyclopedic dictionary of public administration (pp. 1-4). http://www.dictionnaire.enap. ca/dictionnaire/docs/definitions/definitions_anglais/new_management.pdf

Garvin, M., \& Bosso, D. (2008). Assessing the effectiveness of infrastructure public-private partnerships programs and projects. Public Works Management \& Policy, 13(2), 162-178. doi: $10.1177 / 1087724 X 08323845$

Harvey, D. (2005). A brief history of neoliberalism. Oxford University Press.

Hood, C. (1995). The "new public management" in the 1980s: Variations on a theme. Accounting, Organizations and Society, 20(2-3), 93-109. https://doi.org/10.1016/0361-3682(93)E0001-W

NORRAG. (2020). About us: A global membership-based network of international policies and cooperation in education. https://www.norrag.org/

Oldham, S. (2017). Enterprise education: Critical implications for New Zealand curriculum governance. New Zealand Journal of Education Studies, 52, 331-346. https://doi. org/10.1007/s40841-017-0091-2

Osborne, K. (2008). Education and schooling: A relationship that can never be taken for granted. Yearbook of the National Society for the Study of Education, 107, 21-41. doi:10.1111/j.17447984.2008.00128.x

Taylor, A. (2002). Governance. In G. Blakeley \& V. Bryson (Eds.), Contemporary political concepts: A critical introduction (pp. 35-53). Pluto Press. 
McGeown Plant

Tyack, D., \& Cuban, L. (1995). Tinkering toward utopia: A century of public-school reform. Harvard University Press.

Verger, A., Lubienski, C., \& Steiner-Khamsi, G. (2016). World yearbook of education 2016: The global education industry. Routledge.

Webb, S., Holford, J., Hodge, S., Milana, M., \& Waller, R. (2017). Lifelong learning for quality education: Exploring the neglected aspect of sustainable development goal 4.International Journal of Lifelong Education, 36(5), 509-511. https://doi.org/10.1080/02601370.2017.13984 89 